Available online on 15.09.2018 at http://jddtonline.info

Journal of Drug Delivery and Therapeutics

Open Access to Pharmaceutical and Medical Research

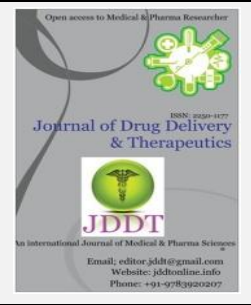

Open $\bigcirc$ Access

Research Article

\title{
POTENTIAL OF CAESALPINIA CRISTA LEAVES IN THE TREATMENT OF ULCERATIVE COLITIS IN LABORATORY ANIMALS
}

\author{
Zaware Bharati $^{1 *}$, Gilhotra Ritu ${ }^{1}$, Chaudhari Sanjay ${ }^{2}$ \\ ${ }^{1}$ Department of Pharmacy, Suresh Gyan Vihar University, Jaipur-302017, Rajasthan, India. \\ ${ }^{2}$ Rasiklal M. Dhariwal Institute of Pharmaceutical Education and Research, Chinchwad, Pune 411019, Maharashtra, India.
}

\begin{abstract}
The aim of present investigation was to study the Ulcerative colitis effect of extracts of Caesalpinia crista in acetic acid induced experimental colitis in Sprague Dawley rats. Sprague Dawley rats were divided into nine groups $(\mathrm{n}=6)$. The rats were received 7 days pretreatment with chloroform, ethyl acetate, ethanolic extracts of C. crista $200 \mathrm{mg} / \mathrm{kg}$ and $400 \mathrm{mg} / \mathrm{kg}$. Ulcerative colitis was induced by intrarectal administration of $1 \mathrm{ml}$ of $4 \%$ acetic acid solution on 8th day. Prednisolone $(2 \mathrm{mg} / \mathrm{kg})$ was used as standard drug administered orally for 3 days. After $48 \mathrm{hrs}$ of colitis induction animals were sacrificed by cervical dislocation to remove colon and distal $5 \mathrm{~cm}$ of the colon was dissected. Macroscopical study, Ulcer index of the colon, colonic myeloperoxidase (MPO) and malondialdehyde (MDA) level in colon tissue and blood were studied. Intrarectal instillation of acetic acid caused enhanced ulcer index, myeloperoxidase and malondialdehyde. Ethanol extract of C.crista showed significant effect in lowering ulcer index as well as neutrophil infiltration at a dose of $400 \mathrm{mg} / \mathrm{kg}$ in acetic acid induced colitis. The present investigation demonstrates that the ethanol extract of C.crista is of potent therapeutic value in the amelioration of experimental colitis in rat by inhibiting the inflammatory mediator.
\end{abstract}

Keywords: Caesalpinia crista, Myeloperoxidase, Malondialdehyde, colitis.

Article Info: Received 04 July, 2018; Review Completed 11 Sep 2018; Accepted 11 Sep 2018; Available online 15 Sep 2018

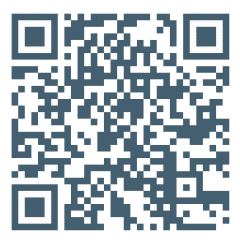

\section{Cite this article as:}

Zaware B, Gilhotra R, Chaudhari S, Potential of caesalpinia crista leaves in the treatment of ulcerative colitis in laboratory animals, Journal of Drug Delivery and Therapeutics. 2018; 8(5):374-381

DOI: http://dx.doi.org/10.22270/jddt.v8i5.1933

Bharati Zaware, Department of Pharmacy, Suresh Gyan Vihar University, Jaipur-302017, Rajasthan, India.

\section{INTRODUCTION}

Ulcerative colitis (UC) and Crohn's disease (CD) are the forms of inflammatory bowel disease (IBD) that is characterized by acute and chronic inflammation of the mucosa, abdominal pain, ulceration of the colon, rectal bleeding, diarrhoea, blood in the stool and weight loss ${ }_{1,2}$. UC can affect similarly both females and males. Although etiology of IBD still remains poorly understood, complex interactions among environmental, genetic, immunological and reactive oxygen species (ROS) have been concerned in the pathogenesis of $\mathrm{IBD}^{3,4}$. The pathological signs in IBD are increase in certain inflammatory mediators, signs of oxidative stress, decreased oxidation of short-chain fatty acids, increased production of sulfide, decreased methylation and also increased intestinal permeability ${ }^{5}$. The increased production of reactive oxygen species plays a significant role in damage of mucosal epithelial layer in IBD patient 6,7 . The more ROS production resulting from respiratory rupture of infiltrating phagocytic cells which causes and decreased antioxidant capacity is an important pathogenic mechanism in IBD ${ }^{8}$. The acetic acid induced ulcerative colitis is broadly used animal models and this model is useful for screening of drugs active against human ulcerative colitis 9, 10. After instillation of acetic acid intrarectally, it causes intracellular acidification resulting in epithelial damage. The massive epithelial damage occurred due to the entry of protons that are released after protonation of acetic acid ${ }^{11}$. The drugs like corticosteroids, 5-amino salicylate, Sulfasalazine, methotrexate and immune modulators are used to treat IBD, but these drugs have 
more adverse effects ${ }^{12}$. Therefore there is need to develop medication to treat IBD. Herbal formulations having polyphenolic and flavonoids derivatives shows good potential for the treatment of IBD like Aloe Vera gel, Wheat grass juice ${ }^{13,14}$.

Caesalpinia crista L. belongs to the family of Fabaceae. It is found all over the hot and humid part of India, Sri Lanka and Myanmar. In India, it is called as Katikaranja and is distributed in Maharashtra, West Bengal and Kerala ${ }^{15}$. Traditionally, in Ayurveda, this plant was used for the treatment of gynecological disorders, skin diseases, constipation, piles and ulcers ${ }^{16}$. C.crista is traditionally used for the treatment of inflammation, tumors and liver disorders ${ }^{17}$. It has been evaluated for a wide range of activity like antipyretic, antidiuretic, anthelmintic, antibacterial, anticonvulsant, antiviral, antiamebic, and antiestrogenic ${ }^{18-20}$.

Hence the objective of present investigation was to evaluate the effect of C.crista in acetic acid induced colitis model of IBD in laboratory animals.

\section{MATERIALS AND METHODS}

This prospective animal study was carried out in Preclinical Research and Development Organization, Pvt. Ltd., Survey No. 170/1, Punawale Road, Tathawade, Pune in March 16. Prior approval of the Institutional Animal Ethics Committee (IAEC) will be obtained before initiation of the study (IAEC-15-010).

\section{Plant material}

The leaves of C.crista L. were collected from rural areas of Ahmednagar district, Maharashtra in the month of November 2014. Authentication of Plant was carried out at Botanical Survey of India, Pune (Voucher specimen number: BBZ02).

\section{Preparation of extract}

A matured leaves of C.crista L. were collected, shade dried and made into a coarse powder and then used for extraction. $1000 \mathrm{gm}$ of the dried powder was extracted with organic solvents like pet ether, chloroform, ethyl acetate, ethanol and water using a soxhlet apparatus. The extract was dried using a rotary evaporator (BUCHI, Rotavapor R-215) under reduced pressure.

\section{Preliminary phytochemical analysis}

The Preliminary phytochemical study of all extracts of C.crista L. was carried out according to standard methods ${ }^{21,22}$. Preliminary phytochemical study of the chloroform, ethyl acetate, ethanol extracts was performed for the identification of phytochemicals may present in extracts.

\section{Animals}

Female Sprague Dawley rats (230-250 gm) were obtained from the National Institute of Bioscience, Pune. (India). 6 rats per cage were housed together in the autoclaved polypropylene cages. Cage changing was done once weekly. They were maintained at $24^{\circ} \mathrm{C} \pm 1{ }^{\circ} \mathrm{C}$, with relative humidity of 45 to $65 \%$ and $12: 12 \mathrm{~h}$ dark/light cycle. The female rats were allowed to acclimatize for five days prior to dosing. During this period, animals were observed daily for clinical signs. The animals were fed with standard rodent diet and filtered water ad libitum throughout the experimental protocol, with the exception of overnight fasting before induction of experimental colitis. The animals had access to filtered water. The experimental protocol was approved by institutional animal ethical committee, Approval No. CPCSEA (IAEC-15-010)

\section{Drugs and chemicals}

Acetic acid, anaesthetic ether, pet ether, chloroform, ethyl acetate, ethanol, formalin, carbon tetrachloride, ethylene glycol, hydrochloric acid and conc. Sulphuric acid were purchased from Poona chemical Lab, Pune, India. Prednisolone was obtained as a gift sample from Wyeth pharma Ltd. Goa, India.

\section{Toxicity studies}

Preeja G, et al., 2011 studied evaluation of acute toxicity of methanol extract of Caesalpinia bonducella (L) Fleming was evaluated in Albino mice. The acute toxicity studies were conducted as per the OECD guidelines 420 where the limit test dose of $2000 \mathrm{mg} / \mathrm{kg}$ used. The extract was found safe up to the dose level of $2000 \mathrm{mg} / \mathrm{kg}$ without any sign of toxicity or mortality ${ }^{23}$.

\section{Dosages of C.crista extract and standard drugs used}

The Freshly prepared test solution of chloroform, ethyl acetate, ethanol extracts of leaves of C.crista in two different dosages $(200 \mathrm{mg} / \mathrm{kg}$ and $400 \mathrm{mg} / \mathrm{kg}$ ) was administered to animals orally for seven days. On 8th day the disease was induced by acetic acid. Drug treatment was continued till 11th day. Prednisolone used as standard drug. Prednisolone and acetic acid treatment was started on the same day.

\section{Pharmacological Screening}

\section{Induction of colitis}

Colonic inflammation was induced in overnight fasted rats. Female Sprague Dawley rats (230-250 gm) were used in the evaluation and were divided in to 9 groups with 6 animals in each group $(n=6)$ as follows:

Group I: (Normal animals) received $2 \mathrm{ml} / \mathrm{kg} /$ day of saline water

Group II: (Control animals) received $1 \mathrm{ml}$ of $4 \%$ acetic acid solution intrarectally on 8th day.

Group III: (Standard group animals) received Prednisolone ( $2 \mathrm{mg} / \mathrm{kg}$, p.o., for 3 days). Acetic acid and Prednisolone treatment was started on the same day.

Group IV, VI, VIII: Animals will receive 7 days pretreatment with $200 \mathrm{mg} / \mathrm{kg}$, of ethanol, ethyl acetate, chloroform extract of C.crista leaves respectively, p.o. and $1 \mathrm{ml}$ of $4 \%$ acetic acid solution, intrarectally on 8th day. Drug treatment was continued till 11th day

Group V, VII. IX: Animals will receive 7 days pretreatment with $400 \mathrm{mg} / \mathrm{kg}$ of ethanol, ethyl acetate, chloroform extract of C.crista leaves respectively, p.o. and $1 \mathrm{ml}$ of $4 \%$ acetic acid solution, intrarectally on 8th day. Drug treatment was continued till 11th day. 
After 48 hours of colitis induction blood was withdraw by retro orbital puncture and rats were sacrificed by cervical dislocation to remove colon. $5 \mathrm{~cm}$ long piece of colon was flushed gently with saline, scored for inflammation based on the macroscopic features. Portions of colonic specimens were kept in $10 \%$ formalin for histopathological studies ${ }^{24,25}$.

\section{Evaluation of the disease}

The intrarectal instillation of acetic acid (1 $\mathrm{ml}$ of 4\%) produced disease in experimental rats, theses disease induced experimental rats was evaluated based on its macroscopic characteristics. In this evaluation $5 \mathrm{~cm}$ long pieces of each rat colon were scored for macroscopic features using scoring pattern ${ }^{26}$.

\section{Determination of ulcer index}

The entire alimentary canal was isolated, opened longitudinally, and washed with phosphate buffer saline. With the help of microscope, ulceration of the opened colon was measured and the ulcer index was calculated by following formula ${ }^{27}$.

Ulcer inde $=\frac{\text { Grade of ulcer in positive control }- \text { Grade of ulcer in test }}{\text { Grade of ulcer in test }- \text { Grade of ulcer in normal control }} \times 100$

\section{Biochemical analysis of colon for MPO and MDA level}

\section{Sample preparation}

The proximal $5 \mathrm{~cm}$ of the dissected colon sample was used for biochemical analysis of myeloperoxidase and malondialdehyde level. The samples of colon were minced and homogenized using a Polytron homogenizer. The supernatant was obtained by centrifuging at $3000 \mathrm{rpm}$ for 20 minutes ${ }^{28}$.

\section{Determination of colonic MPO activity}

Supernatant sample uniformly mixed with citric phosphate buffer which having pH 5.0 containing 0.4 $\mathrm{mg} / \mathrm{mL}$ O-phenylene diamine and $0.015 \%$ hydrogen peroxide. The change in absorbance measured spectrophotometrically at $492 \mathrm{~nm}$. Test absorbance compared with the standard dilution with horseradish peroxidase. Myeloperoxidase (MPO) was expressed in units per gram (U/gm) of wet scrapings ${ }^{29,30}$.

\section{Determination of MDA level}

Reaction mixture containing $0.1 \mathrm{ml}$ of tissue sample, 0.2 $\mathrm{ml}$ of $8.1 \%$ sodium dodecyl sulfate LR, $1.5 \mathrm{ml}$ of $2 \%$ acetic acid, and $1.5 \mathrm{ml}$ of $0.8 \%$ aqueous solution of thiobarbituric acid LR. Mixture $\mathrm{pH}$ was adjusted to 3.5 and volume was finally made up to $4 \mathrm{ml}$ with distilled water and $5 \mathrm{ml}$ of mixture of $n$-butanol and $15 \%$ pyridine was added. This mixture was shaken vigorously. After centrifugation at $4000 \mathrm{rpm}$ for $10 \mathrm{~min}$, the absorbance of organic layer was measured spectrophotometrically at $532 \mathrm{~nm}$. Malondialdehyde (MDA) was expressed in units per gram $(\mathrm{U} / \mathrm{gm})$ of protein $^{31}$.

\section{Histopathological studies}

The sample of colon from each group was washed with saline and tissue was fixed with $10 \%$ formalin for histopathological studies. It was processed for 24-36 hours and then trimmed at appropriate site and washed below running tap water for 2 hours then tissue is dehydrated using solvent alcohol LR. Then, the tissue was washed with xylene LR and fixed with paraffin wax. 5-mm thick tissue was deparafinnated and deep in the xylene for $3 \mathrm{~min}$. Sections were rehydrated with alcohol, kept $5 \mathrm{~min}$ in water and $10 \mathrm{~min}$ in hematoxylin LR. Deep in $1 \%$ ammonia water was done and immediately washed under running tap water. Add 2 or 3 drops of alcoholic eosin and dehydrated with alcohol. Again slides were cleaned with xylene. Stained with Hematoxylin-Eosin and examined under microscope.

\section{Statistical analysis}

The values Mean \pm S.E.M are calculated for each parameter. Data analysis was performed using Graph Pad Prism 5.0 software. All the result obtained in the study was compared between drug-treated groups and control group. All data of biochemical parameters were analyzed using one-way ANOVA; Dunnett's multiple range tests was applied for post hoc analysis. A value of $P<0.05$ was considered to be statistically significant.

\section{RESULTS}

\section{Preliminary phytochemical analysis}

The preliminary phytochemical analysis of C.crista extracts exposed the presence of phytoconstituents like carbohydrates, alkaloids, flavonoids, phenols, glycosides and terpenoids (Table 1)

Table 1: Preliminary Phytochemical Test For Extracts of $\boldsymbol{C}$. crista $\mathbf{L}$. Leaves

\begin{tabular}{|l|l|l|l|l|}
\hline Sr.No. & Test & Chloroform & Ethyl acetate & Ethanol \\
\hline & Alkaloids & + & + & + \\
\hline & Glycosides & + & + & + \\
\hline & Carbohydrates & + & + & + \\
\hline & Terpenoids & - & - & + \\
\hline & Phenols & - & + & + \\
\hline & Flavonoids & - & + & + \\
\hline & Proteins & - & - & - \\
\hline & Saponins & - & - & - \\
\hline & Tannins & + & + & - \\
\hline & Steroids Note: + positive result, - negative result & - \\
\hline
\end{tabular}




\section{Acetic acid-induced colitis}

As observed from this study, intrarectal administration of $1 \mathrm{ml}$ of $4 \%$ acetic acid to the experimental control group caused inflammation to the colon, when compared to the normal control group. Ethanol extract treated group animal showed significant suppressed of inflammatory reaction.

Effect of C.crista extracts on macroscopic score
After intrarectal administration of $1 \mathrm{ml}$ of $4 \%$ acetic acid, the colons of the rats were examined macroscopically for signs of hemorrhage, ulceration and inflammations by an independent observer, in a blinded fashion. The mean macroscopical score in acetic acid control group rats was found to be significantly increased $(P<0.01)$ as compared to normal group rats. 200 and $400 \mathrm{mg} / \mathrm{kg}$ ethanol extract of $C$. crista had decreased macroscopical lesions of colon showed better effect comparably with standard drug (Table 2).

Table 2: Effect of Extracts of C.crista on Macroscopic Score of Rat in Acetic Acid Induced Ulcerative colitis

\begin{tabular}{|l|l|}
\hline Treatment & Macroscopical score \\
\hline Normal & $0.00 \pm 0.00$ \\
\hline Control $(4 \%$ Acetic acid $)$ & $8.1 \pm 0.35^{\text {\#\# }}$ \\
\hline Prednisolone $(2 \mathrm{mg} / \mathrm{kg})$ & $3.00 \pm 0.40$ \\
\hline ECC $(200 \mathrm{mg} / \mathrm{kg})$ & $4.83 \pm 0.55^{* * *}$ \\
\hline ECC $(400 \mathrm{mg} / \mathrm{kg})$ & $4.16 \pm 0.38^{* * *}$ \\
\hline EACC $(200 \mathrm{mg} / \mathrm{kg})$ & $6.16 \pm 0.46^{*}$ \\
\hline EACC $(400 \mathrm{mg} / \mathrm{kg})$ & $5.33 \pm 0.40^{* *}$ \\
\hline CCC $(200 \mathrm{mg} / \mathrm{kg})$ & $7.50 \pm 0.50$ \\
\hline CCC $(400 \mathrm{mg} / \mathrm{kg})$ & $7.00 \pm 0.45$ \\
\hline
\end{tabular}

Values expressed as mean \pm S.E.M (n=6) and analyze by ANOVA followed by Dunnett's test. $* P<0.05, * * P<0.01, * * * P<0.001$ as compared to acetic acid control group; \#\#\# $p<0.001$ when compared to normal group

\section{Effect of C.crista extracts on ulcer protection}

Acetic acid induced control group of animal showed less protective effect in ulcer index. The 7 days pretreatment of 200 and $400 \mathrm{mg} / \mathrm{kg}$ ethanol extract of C. crista had showed a better protective effect in ulcer index (Table 3).

Effect of $C$. crista extracts on colonic MPO and MDA concentrations

The colitis caused by acetic acid was associated with increase in MPO and MDA concentrations. 200 and 400 $\mathrm{mg} / \mathrm{kg}$ ethanol extract of C.crista found best in reducing myeloperoxidase and malondialdehyde activity in tissues which was raised by the acetic acid (Table 4 and Figure $1,2)$.
Table 3: Effect of Extracts of C.crista on Ulcer Protection

\begin{tabular}{|l|c|}
\hline Treatment & $\begin{array}{c}\text { Microscopic ulcer index } \\
(\%)\end{array}$ \\
\hline Normal & 100 \\
\hline Control $(4 \%$ Acetic acid $)$ & 00 \\
\hline Prednisolone $(2 \mathrm{mg} / \mathrm{kg})$ & 91 \\
\hline ECC $(200 \mathrm{mg} / \mathrm{kg})$ & 50 \\
\hline ECC $(400 \mathrm{mg} / \mathrm{kg})$ & 62 \\
\hline EACC $(200 \mathrm{mg} / \mathrm{kg})$ & 23 \\
\hline EACC $(400 \mathrm{mg} / \mathrm{kg})$ & 40 \\
\hline CCC $(200 \mathrm{mg} / \mathrm{kg})$ & 17 \\
\hline CCC $(400 \mathrm{mg} / \mathrm{kg})$ & 30 \\
\hline
\end{tabular}

Table 4: Effect of Extracts of C. Crista on Myeloperoxidase (MPO) Activity and Malondialdehyde (MDA) Activity.

\begin{tabular}{|l|l|l|}
\hline Treatment & $\begin{array}{l}\text { Myeloperoxidase } \\
\text { activity in tissue(U/gm) }\end{array}$ & $\begin{array}{l}\text { Malondialdehyde } \\
\text { activity in tissue(U/gm) }\end{array}$ \\
\hline Normal & $6.2 \pm 0.45$ & $2.25 \pm 0.27$ \\
\hline Control $(4 \%$ Acetic acid) & $15.93 \pm 0.37^{\# \#}$ & $9.50 \pm 0.39^{\# \#}$ \\
\hline Prednisolone $(2 \mathrm{mg} / \mathrm{kg})$ & $12.40 \pm 0.44$ & $4.82 \pm 0.44$ \\
\hline ECC $(200 \mathrm{mg} / \mathrm{kg})$ & $13.55 \pm 0.41^{* *}$ & $7.09 \pm 0.41^{* *}$ \\
\hline ECC $(400 \mathrm{mg} / \mathrm{kg})$ & $13.00 \pm 0.43^{* * *}$ & $5.37 \pm 0.33^{* * * *}$ \\
\hline EACC $(200 \mathrm{mg} / \mathrm{kg})$ & $14.29 \pm 0.40^{* *}$ & $7.51 \pm 0.54^{*}$ \\
\hline EACC $(400 \mathrm{mg} / \mathrm{kg})$ & $14.25 \pm 0.43^{* *}$ & $7.46 \pm 0.41^{*}$ \\
\hline CCC $(200 \mathrm{mg} / \mathrm{kg})$ & $15.43 \pm 0.34$ & $8.41 \pm 0.39$ \\
\hline CCC $(400 \mathrm{mg} / \mathrm{kg})$ & $15.23 \pm 0.39$ & $8.30 \pm 0.42$ \\
\hline
\end{tabular}

Values expressed as mean \pm S.E.M ( $\mathrm{n}=6)$ and analyze by ANOVA followed by Dunnett's test. $* P<0.05, * * P<0.01, * * * P<0.001$ as compared to acetic acid control group; \#\#\# $p<0.001$ when compared to normal group 


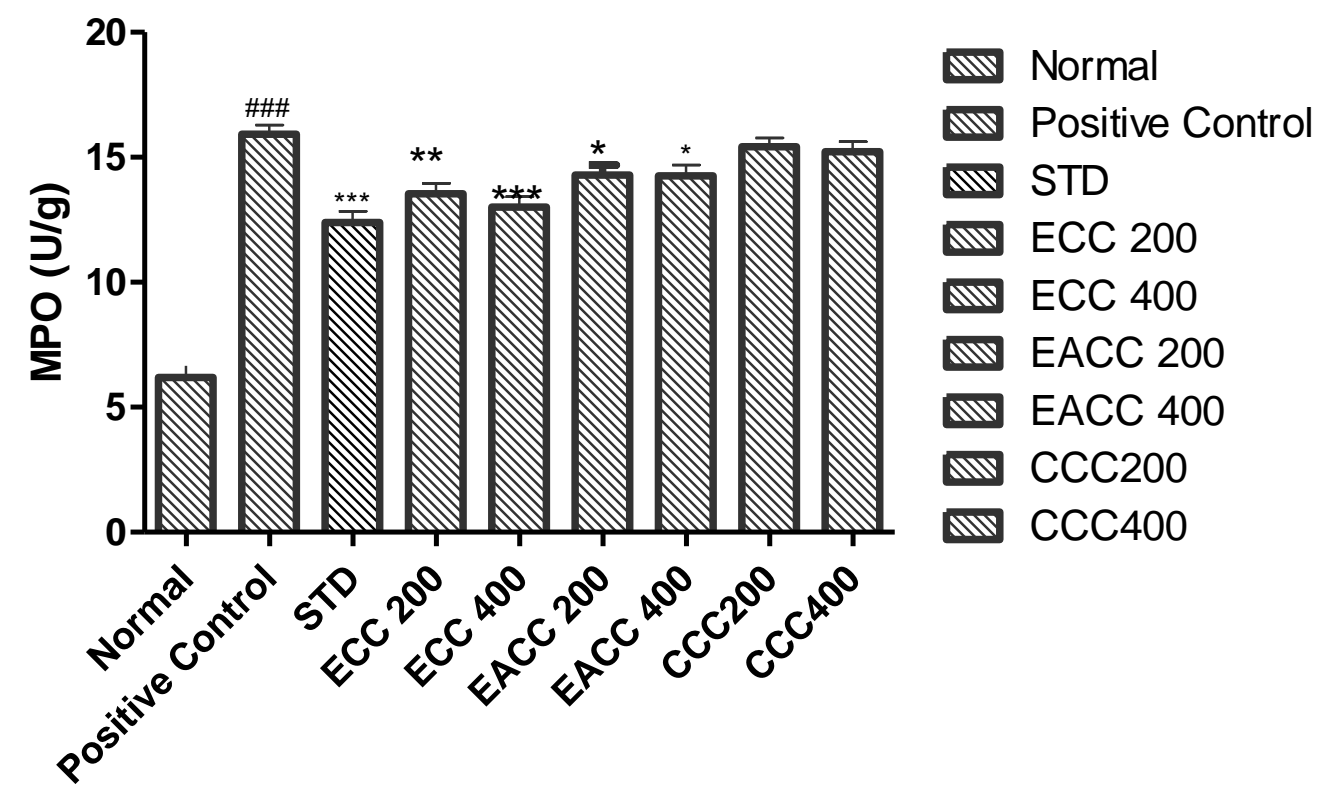

Treatment

Figure 1: Effect of Extracts of $\boldsymbol{C}$. crista on colonic MPO concentrations in acetic acid induced colitis.

Data are expressed as mean \pm S.E.M. from five rats and analyze by one way ANOVA followed by Dunnett's test. $* P<0.05$, $* * P<$ $0.01, * * * P<0.001$ as compared to acetic acid control group; \#\#\# $p<0.001$ when compared to normal group

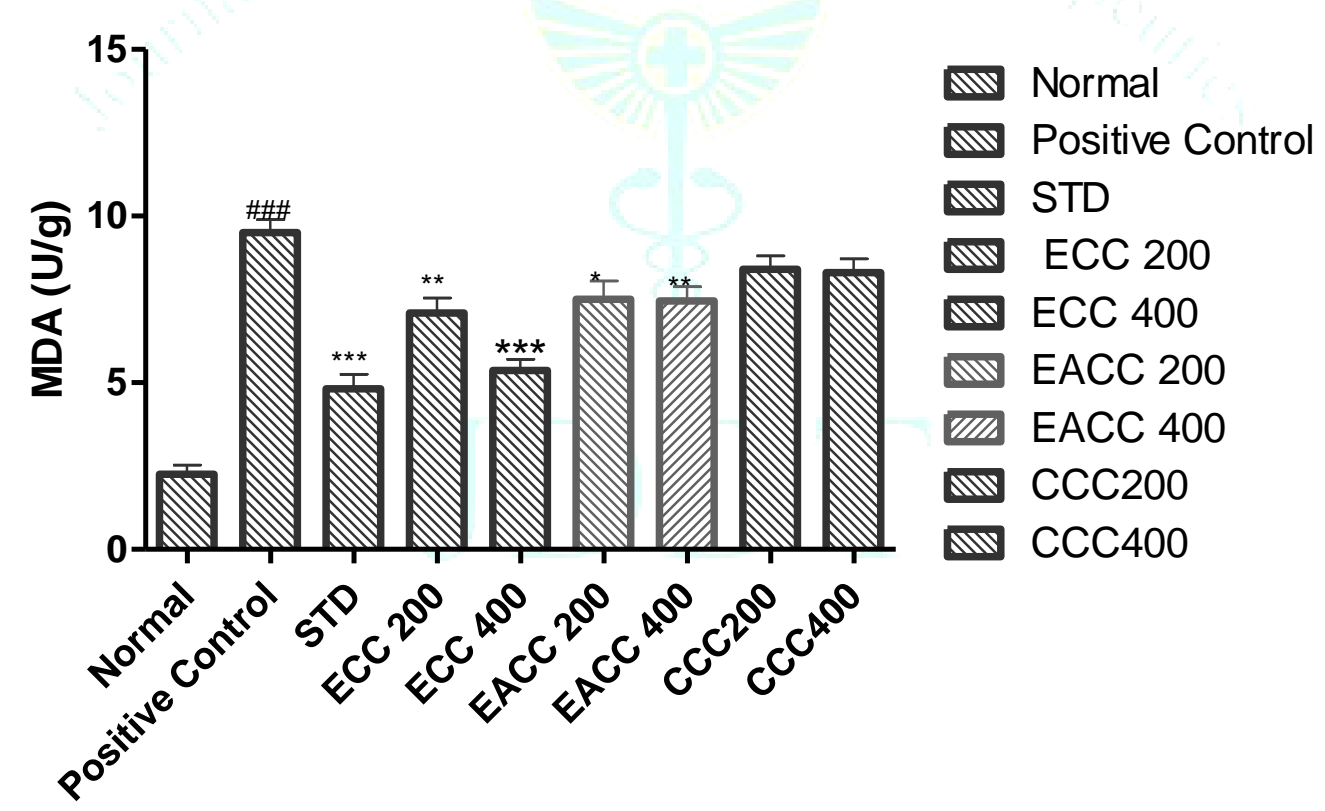

Treatment

Figure 2: Effect of Extracts of $\boldsymbol{C}$. crista on colonic MDA level in acetic acid induced colitis.

Data are expressed as mean \pm S.E.M. from five rats and analyze by one way ANOVA followed by Dunnett's test. $* P<0.05$, $* * P<$ $0.01,{ }^{*} * * P<0.001$ as compared to acetic acid control group; \#\#\# $p<0.001$ when compared to normal group

\section{Histopathological study}

Study the hematoxylin and eosin stained sections of ulcerated parts of the colon of the rats for indication of colitis. Histopathological study showed transmural necrosis, ulceration, edema, hemorrhages, hyperemia, and cellular infiltration in the colon of rat treated with 1 $\mathrm{ml}$ of $4 \%$ acetic acid (Figure 3). The seven days pretreatment of $400 \mathrm{mg} / \mathrm{kg}$ of ethanol extract of C. crista found to be preventive progression of colitis. The preventive effect observed by morphologically as well as Histopathological study also (Table 5, Figure 3). 
Table 5: Histopathological observations after the treatment with extracts of C.crista

\begin{tabular}{|l|l|l|l|l|l|l|}
\hline Treatment & Ulceration & Hyperemia & Necrosis & Edema & $\begin{array}{l}\text { Cellular } \\
\text { Infiltration }\end{array}$ & $\begin{array}{l}\text { Goblet-cell } \\
\text { hyperplasia }\end{array}$ \\
\hline Normal & 0 & 0 & 0 & 0 & 0 & 0 \\
\hline$(4 \%$ Acetic acid) & ++++ & ++++ & ++++ & ++++ & ++++ & ++++ \\
\hline Prednisolone $(2 \mathrm{mg} / \mathrm{kg})$ & + & ++ & + & + & + & ++ \\
\hline ECC $(200 \mathrm{mg} / \mathrm{kg})$ & ++ & ++ & +++ & ++ & ++ & +++ \\
\hline ECC $(400 \mathrm{mg} / \mathrm{kg})$ & ++ & + & + & + & ++ & ++ \\
\hline EACC $(200 \mathrm{mg} / \mathrm{kg})$ & +++ & ++ & +++ & ++ & ++ & +++ \\
\hline EACC $(400 \mathrm{mg} / \mathrm{kg})$ & ++ & ++ & +++ & +++ & ++ & +++ \\
\hline CCC $(200 \mathrm{mg} / \mathrm{kg})$ & +++ & ++ & +++ & +++ & ++ & +++ \\
\hline CCC $(400 \mathrm{mg} / \mathrm{kg})$ & ++ & +++ & +++ & ++ & +++ & +++ \\
\hline
\end{tabular}

(0): no abnormality detected; (+): damage/ active changes up to less than 25\%; (++): damage/active changes up to less than $50 \%$; $(+++)$ : damage/active changes up to less $75 \% ;(++++)$ : damage/ active changes up to more than $75 \%$
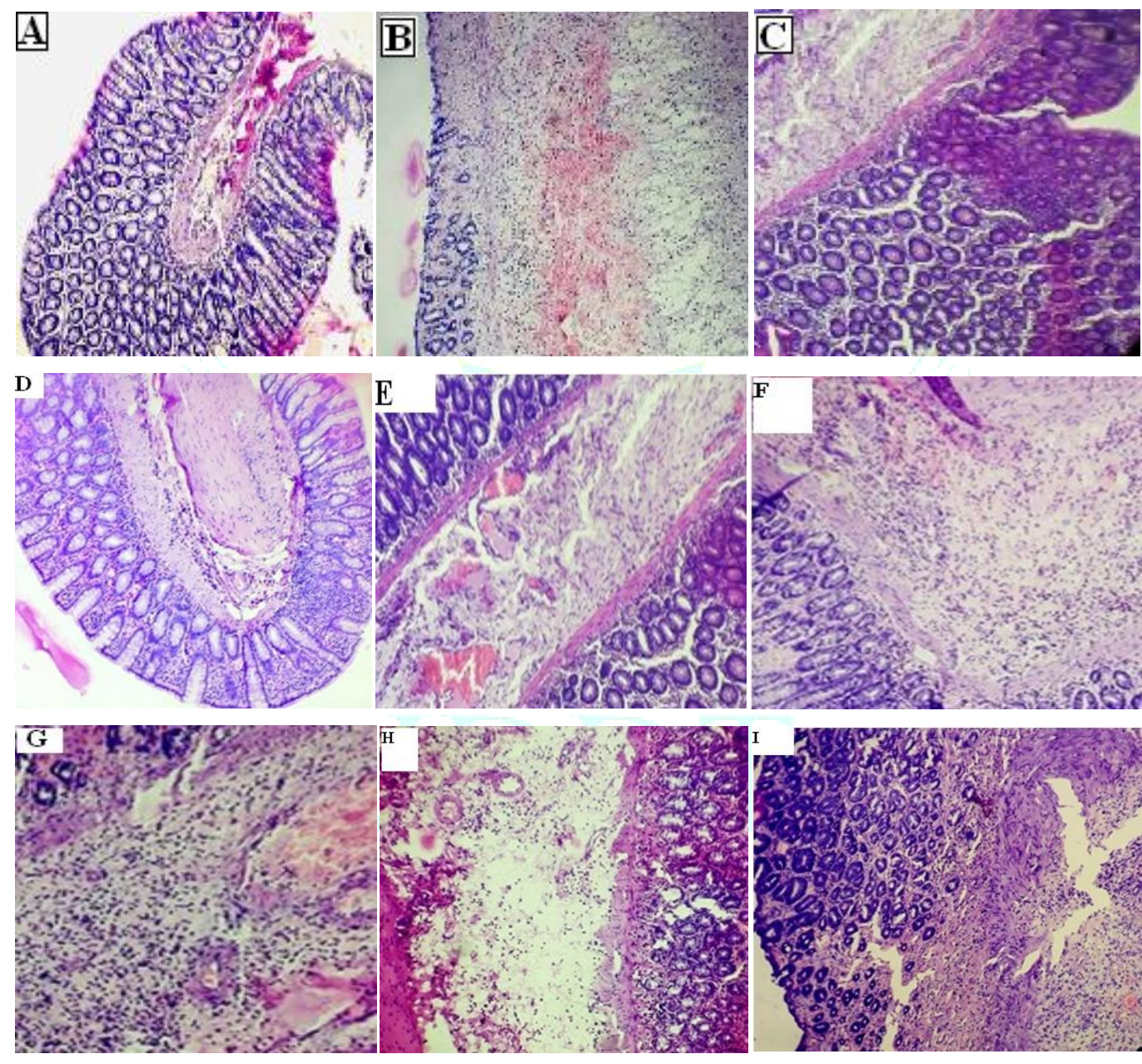

Figure 3: Photomicrographs of sections of colons from rats stained with H\&E.

Histopathological observations of colon tissue after the treatment with C.crista leave extract. (A) Normal; (B) Control (4\% acetic acid); (C) Prednisolone (2mg/kg); (D) Ethanol extract $(200 \mathrm{mg} / \mathrm{kg})$; (E) Ethanol extract (400mg/kg); (F) Ethyl acetate (200mg/kg);(G) Ethyl acetate (400mg/kg); (H) Chloroform (200mg/kg);(I) Chloroform (400mg/kg).

\section{DISCUSSION}

In traditional system of medicine, C.crista plant has been helpful in ulcers though the review also reveals that the plant has not been screened scientifically for ulcerative colitis. This study was to validate its folk use in the treatment of ulcerative colitis by using acetic acidinduced colitis in rats.

Acetic acid induced colitis in rats model is one of the mostly used experimental models while screening drugs effective against ulcerative colitis. The intrarectal instillation of acetic acid produces inflammation appears to involve the entry of the acid which is in the protonated form within the intracellular space and causes intracellular acidification resulting in massive epithelial damage and localized erosion of the colonic mucosa leading to hemorrhages, transmural necrosis, ulceration, edema, and severs localized inflammation and activates cyclooxygenase enzymes and lipooxygenase enzymes pathways which results 
generation of inflammatory mediators likes leukotrienes and prostaglandin ${ }^{32-34}$. Mucosal immune system is the most important effectors of intestinal injury and inflammation, with cytokines playing a main role in modulating inflammation ${ }^{35,36}$. In this work increased levels of both TNF- $\alpha \square$ and PGE2, caused edema, epithelial cell necrosis and neutrophil infiltration as observed in the histopathological study.

Ethanolic extract of $C$. crista has significant protective activity against experimental colitis in rats, as indicated by microscopic, macroscopic observations ulcer index and other biochemical evaluations.

Ulcer index were quantitatively determined. Pretreatment of ethanol extract showed a better protective effect in ulcer index than other extract comparable with the standard drug.

Myeloperoxidase (MPO) is a peroxidase enzyme generally found in neutrophil granulocytes. It is a very good marker of tissue inflammation, injury and neutrophil infiltration. Acetic acid raised the levels of colonic Myeloperoxidase (MPO), indicating infiltration of neutrophil it specify that neutrophil accumulation contributes to the colitis induce oxidative injury ${ }^{37}$. Pretreatment with ethanol extract of $C$. crista ameliorated neutrophil infiltration as evidenced by decreased the colon Myeloperoxidase (MPO) level and development of histological features ${ }^{38,39}$.

\section{REFERENCES}

1. Jagtap AG, Shirke SS, Phadke AS, Effect of polyherbal formulation on experimental models of inflammatory bowel diseases, J Ethnopharmacol, 2004; 90(2-3):195-204.

2. Papadakis KA, Targan SR, Role of cytokines in the pathogenesis of inflammatory bowel disease, Annu Rev Med, 2000; 51:289-98.

3. Fiocchi C, Inflammatory bowel disease: Etiology and pathogenesis, Gastroenterology, 1998; 115:182-205.

4. Papadakis KA, Targan SR, Current theories on the cause of inflammatory bowel disease, Gastroenterol Clin North Am, 1999; 28:283-96.

5. Rutgeerts $\mathrm{P}$, Geboes $\mathrm{K}$, Understanding inflammatory bowel disease-the clinician's perspective, Eur J Surg Suppl, 2001; 586:66-72.

6. Hyam SR, Jang SE, Jeong JJ, Joh EH, Han MJ, Kim DH, Echinocystic acid, a metabolite of lancemaside A, inhibits TNBS-induced colitis in mice, International Immunopharmacology, 2013; 15:433-41.

7. Pullman WE, Elsbury S, Kobayashi M, Hapel AJ, Doe WF, Enhanced mucosal cytokineproduction in inflammatory bowel disease, Gastroenterology, 1992; 102:529-37.

8. Mohsen M, Alireza G, Parvin M, Elham JS, Comparative study of Beeberis vulgaris fruit extract and Berberin chloride effect on acetic acid induced colitis in rats, Iranian Journal of Pharmaceutical Research, 2011; 10: 97-104.

9. Ashry EE, Abdellatief RB, Mohamed AE, Kotb HI, Protective effect of Ketamine against acetic acid induced ulcerative colitis in rats, Pharmacology and Pharmacy, 2016; 7:9-18.

10. Strober W, Fuss IJ, Blumberg RS, The immunology of mucosal models of inflammation, Annual Review Immunology, 2002; 20: 495-549.

11. Fabia R, Willen R, Rajab AA, Andersson R, Ahren B, Bengmark $\mathrm{S}$, Acetic acid-induced colitis in the rat: Areproducible experimental model for acute ulcerative colitis, Eur. Surg. Res, 1992; 24:211-25.
Malondialdehyde (MDA) is a very good indicator of lipid peroxidation ${ }^{40}$, which is found to be raised in colonic tissue of the rats which are treated with acetic acid. Elevated level of lipid peroxidation can initiate vicious cycles that produce reactive metabolites, which weaken cellular antioxidants and help the development of more inflammation. Pretreatment of ethanol extract of C. crista increase colonic oxidative balance in rats on colitis since it was able to reduce the malondialdehyde level significantly ${ }^{41}$.

The $C$. crista contains phytochemicals like alkaloids, flavonoids, glycosides and phenolic compounds. The present results may lead pharmacological support to folk, ethno medical uses of plant in the management of IBD disorders. Phenolic and Flavonoids substances found in green plants which possess antioxidant and anti-inflammatory property ${ }^{42}$.

\section{CONCLUSION}

It can be concluded that ethanol extract $C$ crista leaves possesses potent activity against various pathological changes caused by administration of acetic acid. The flavonoids derivatives present in $C$ crista may possess antioxidant as well as anti-inflammatory potential against acetic acid induced experimental colitis by inhibition of release of oxido-inflammatory mediators like MPO and MDA.

12. Mashtoub S, Hoang BV, Vu M, Lymn KA, Feinle-Bisset C, Howarth GS, Clinical and structural effects of traditional Chinese medicine and the herbal preparation, Iberogast, in a rat model of ulcerative colitis, J Evid Based Complementary Altern Med, 2014; 19(1):10-9.

13. Rahimi R, Mozaffari S, Abdollahi M, On the use of herbal medicines in management of inflammatory bowel diseases: a systematic review of animal and human studies, Digestive Diseases and Science, 2009; 54:471-80.

14. Fei Ke, Yadav PK, Liuzhan Ju, Herbal medicine in the treatment of Ulcerative colitis, The Saudi Journal of Gastroenterology, 2012; 18 (1):3-10.

15. S. K. Kalauni, S. Awale, Y. Tezuka, A. H. Banskota, T. Z. Linn, and S. Kadota, "Methyl migrated cassane-type furanoditerpenes of Caesalpinia crista from Myanmar," Chemical and Pharmaceutical Bulletin, 2005; 53(10):13001304.

16. Williamson EM. Major Herbs of Ayurveda, Elsevier Health Sciences, Edinburgh. UK: 2002.

17. Kirtikar KR, Basu BD. Indian medicinal plants. Vol 2, 2nd ed. Dehradun, India: Bishen Singh Mahendra Pal Singh; 1975. P. 842-844.

18. Neogi NC, Nayak KP. Biological investigation of Caesalpinia bonducella F. Indian J Pharmacol 1958; 20:95100 .

19. Adesina SK, Studies on some plants used as anticonvulsant in Amerindian and African traditional medicine, Fitoterapia, 1982; 53:147-162.

20. Dhar ML, Dhar MM, Dhawan BN, Mehrotra BN, Roy C, Screening of Indian plants for biological activity, Indian $\mathrm{J}$ Exp Biol, 1968;6:232-247.

21. Khandelwal KR. Practical Pharmacognosy Techniques and Experiments. 8th ed. Pune: Nirali Prakashan; 2007. P 149-53.

22. Kokate CK. Practical Pharmacognosy. New Delhi: Vallabh Prakashan; 2005. P 107-08, 115-20, 122-23.

23. Preeja G, Pillaia , Suresh P, European J Scientific Research, 2011; 53:462-469 
24. Millar AD, Rampton DS, Chander CL, Evaluating the antioxidant potential of new treatments for inflammatory bowel disease using a rat model of colitis, Gut, 1996; 39(3):407-15.

25. Mascolo N, Izzo A, Autore G, Maiello F, Carlo G, Capasso $\mathrm{F}$, Acetic acid- induced colitis in normal and essential fatty acid deficient rats, J Pharmacol Exp Ther, 1995; 272:469-75.

26. Morris GP, Beck PL, Herridge MS, Depew WT, Szewczuk MR, Wallace JL, Hapten-induced model of chronic inflammation and ulceration in the rat colon, Gastroenterology, 1989; 96:795-803.

27. Zaware BB, Nirmal SA, Baheti DG, Patil AN, Mandal SC, Potential of Vitex negundo roots in the treatment of ulcerative colitis in mice, Pharmaceutical Biology, 2011; 49(8):1-5.

28. Murat Z, Mustafa K, Erhan A, Ozgur F, Murat A, Gokhan I, The comparative effects of calcium channel blockers in an experimental colitis model in rats, Turk $\mathrm{J}$ Gastroenterol, 2004; 15:243-49.

29. Dighe SB, Kuchekar BS, Wankhede SB, Potential Of Oxalis Corniculata Linn in the treatment of Ulcerative colitis, International Journal of Pharma and Bio Science, 2015; 6(3):117-25.

30. Evans M, Laszlo R, Brendan J, Whitlle R, Site specific lesion formation inflammation and inducible nitric oxide synthase expression by indomethacin in the rat intestine, European Journal Pharmacology, 2000; 388:281-85.

31. Ganjare AB, Nirmal SA, Patil AN, Use of apigenin from Cordia dichotoma in the treatment of colitis, Fitoterapia, 2011; 82:1052-56.

32. Jagtap AG, Shirke SS, Phadke AS, Effect of polyherbal formulation on experimental models of inflammatory bowel disease, Journal of Ethnopharmacology, 2004; 90:195-204

33. Nakhai LA, Mohammadirad A, Yasa N, Minaie B, Nikfar S, Ghazanfari G, Benefits of Zataria multiflora Boiss in experimental model of mouse inflammatory bowel disease,
Evidence- Based Complementary Alternative Medicine, 2007; 4:43-50.

34. Macpherson B, Pfeiffer C, Experimental production of diffuse colitis in rats, Digestion, 1978; 17:135-50.

35. Ardizzone S, Bianchi PG, Biologic therapy for inflammatory bowel disease. Drugs, 2005; 65:2253-86.

36. Nakamura K, Honda K, Mizutani T, Akiho H, Harada N, Novel strategies for the treatment of inflammatory bowel disease: Selective inhibition of cytokines and adhesion molecules, World Journal of Gastroenterology, 2006; 12(29):4628-35.

37. Krawisz JE, Sharon P, Stenson WE, Quantitative assay for acute intestinal inflammation based on myeloperoxidase activity, Assessment of inflammation in rat and hamster models, Gastroenterology, 1984; 87:1344-50.

38. Joshi SV, Vyas BA, Shah PD, Shah DR, Shah SA, Gandhi TR, Protective effect of aqueous extract of Oroxylum indicum Linn. (root bark) against DNBS-induced colitis in rats, Indian Journal of Pharmacology, 2011; 43(6):656-61.

39. Shiratora Y, Aoki S, Takada H, Kiriyama H, Ohto K, Hai K, Oxygen-derived free radical generating capacity of polymorphonuclear cells in patients with ulcerative colitis, Digestion, 1989; 44:163-71.

40. Zama D, Meraihi Z, Tebibel S, Benayssa W, Benayache F, Benayache S, Chlorpyrifos-induced oxidative stress and tissue damage in the liver, kidney, brain and fetus in pregnant rats: The protective role of the butanolic extract of Paronychia argentea L, Indian Journal of Pharmacology, 2007; 39(3):145-50.

41. Ohkawa H, Ohishi N, Yagi K, Assay for lipid peroxidase in animal tissues by thiobarbituric acid reaction, Analytical Biochemistry, 1979; 95:351-58.

42. Sharma V, Rajani GP, Evaluation of Caesalpinia pulcherrima Linn. for anti-inflammatory and antiulcer activities, Indian Journal of Pharmacology, 2011; 43(2):16871. 